\title{
Development of Authentic Assessment Instruments Oriented Reading Skills Based Language Literacy through the Scaffolding Model
}

\author{
Makhroji', Irma Dewi Isda², Allif Syahputra Bania3 \\ DOI: $10.35445 /$ alishlah.v13i3.976
}

\begin{abstract}
Article Info
Abstract

Keywords:

Authentic, Reading

Skills, Language

Literacy

This research aims to develop an authentic assessment instrument product based on language literacy with a scaffolding model that is oriented towards reading skills. This research method uses research and development methods. The research results show that the preliminary research phase describes the results of curriculum analysis and student analysis. At the product development stage and validation by experts, the percentage of authenticity instrument eligibility consisting of three indicators is $82 \%$. It can be concluded that the instrument is suitable for use in learning activities. The practicality stage given to 20 students in one of the Manyak Payed Public High Schools, Aceh Tamiang District, consisted of four alternative answers, $25 \%$ were declared practical. Thus, high school teachers are advised to use the scaffolding model as a solution to improve reading comprehension and language literacy skills.
\end{abstract}

Kata kunci:

Autentik, Keterampilan

Membaca, Literasi

Bahasa

\begin{abstract}
Abstrak
Tujuan dari penelitian ini adalah untuk mengembangkan produk instrument penilaian autentik berbasis literasi Bahasa dengan model scaffolding yang berorientasi keterampilan membaca. Metode penelitian ini menggunakan metode research and development. Dari hasil penelitian diketahui bahwa tahap investigasi awal (Preliminary Research Phase) mendeskripsikan hasil analisis kurikulum dan analisis peserta didik. Pada tahap pengembangan produk dan validasi oleh ahli, persentase kelayakan instrument auntentik yang terdiri dari tiga indikator sebesar $82 \%$ dapat disimpulkan instrument layak digunakan dalam proses kegitan pembelajaran. Tahap kepraktisan yang diberikan kepada siswa yang berjumlah 20 di salah satu SMA Negeri Manyak Payed Kabupaten Aceh Tamiang, terdiri dari empat alternatif jawaban sebesar 25\% dinyatakan praktis. Dengan demikian, kepada guru SMA disarankan untuk menggunakan model scaffolding sebagai salah satu solusi meningkatkan kemampuan membaca pemahaman literasi bahasa.
\end{abstract}

\footnotetext{
${ }^{1}$ Universitas Samudra, Aceh, Indonesia

email: makhroji@unsam.ac.id

2 Universitas Samudra, Aceh, Indonesia

email: irmaisda.fkip@unsam.ac.id

3 Universitas Samudra, Aceh, Indonesia

email: allifbania@unsam.ac.id
} 


\section{INTRODUCTION}

Learning and teaching (formal or informal) can't be comprehended without a dynamic approach to scaffolding (Geert and Steenbeek, 2005). Scaffolding is key to this dynamic systems concept of learning and teaching. A case study of five students in a special education school illustrates the methodology. We need to conduct a further empirical study to test the model's predictions about non-linear learning and teaching phenomena. Scaffolding and learning processes observed in real-world situations require a richer model of embodied and socially situated dynamics of concern-governed action in addition to the fundamental dynamic model described above.

According to Janneke van de Pol and Monique Volman (2010), there has been a tremendous increase in the number of thorough descriptions and classifications of different scaffolding systems over the past decade. In this review, the characteristics of scaffolding, which include fading, contingency, and the transfer of responsibilities, are highlighted. Future scaffolding assessments should pay close attention to these important properties. The existing research body is synthesized to provide an extra framework for the more accurate study of scaffolding techniques, which may be used to measure scaffolding. Means and intentions are separated in the scaffolding process. For example, students' cognitive and metacognitive activities are researched more extensively than students' effects. Students' cognitive activities are the primary focus of modeling and questioning methods research.

Reading is a component of the educational process, as stated in Permendikbud No. 67 of 2013 on the Basic Framework and Curriculum Structure: "the educational process is a process that enables students to develop their potential into rational thinking abilities and academic brilliance by providing meaning to what is seen, heard, read, and learned from cultural heritage through the cultural lens and at the level of psyche." Reading is critical to the process of learning and intellectual development. The quality of human life is determined by humans' ability to maximize their potential (Setyanto et al., 2020). Reading is one way to maximize one's self-potential. In other words, reading, according to Bambang (2011), is a way for humans to discover the boundaries of knowledge.

According to Krismanto et al. (2015), reading is one of the fundamental talents that humans must possess in the current and future generations. This is consistent with Bambang's (2011) assertion that reading has not become a requirement for the Indonesian population. The majority of teachers' approach to reading comprehension is one that burdens kids. To address the issues outlined previously, teachers should teach children reading methods and encourage them to utilize them. According to Majdi et al. (2009), one critical aspect of reading instruction has been overlooked: the need to teach students appropriate pedagogic competence, which includes an understanding of students, designing and implementing instruction, evaluating learning outcomes, and developing students to actualize their various potential reading strategies. Teachers are responsible for teaching pupils about reading methods and how to apply them. To ensure comprehension, teachers should assist students in grasping and employing reading skills.

Students are only expected to comprehend what is openly written in the reading text while they are learning to read literacy comprehension. According to Dalman (2013), reading comprehension literacy is a reading activity that enables students to comprehend the meaning included in the reading text. Supriyono (2018) asserts that comprehension of literacy can be enhanced by recognizing information contained in texts, comparing information contained in texts, and identifying information contained in texts. The reader's schemata, the reader's ability to remember, the reader's perspective, the reader's ability to think, and the affective aspect all influence reading comprehension literacy. The text used in 2014 literacy reading comprehension instruction is descriptive. According to Siahaan and Shinoda (2008), a description is Englishlanguage writing in which the author describes an object. According to Luke and Freebody (in 
Gibbons, 2002), pupils as readers can take on the roles of a codebreaker, a text participant, a text user, or a text analyst.

Scaffolding is inextricably linked to the ZPD, or Zone of Proximal Development, which refers to the space between the ability to perform tasks independently and the inability to perform tasks autonomously (Walqui \& Aida, 2006). Gibbons (2002) defines scaffolding as "help provided by teachers to pupils when they are unable to finish assignments independently." The qualities of scaffolding include continuity, contextual support, intersubjectivity, contingency, handover/takeover, and flow. Six types of scaffolding can assist students in learning to read: modeling, contextualization, schema construction, text re-presentation, and metacognition development. The scaffolding technique consists of three stages: pre-reading, reading, and postreading.

This scaffolding model assists students in simulating the topic assignments assigned by the teacher. Additionally, this strategy teaches students to be more self-sufficient in locating knowledge from teacher-assigned assignments. Thus, when a teacher assigns work to a class, the teacher assesses the students using an authentic assessment method. It is hoped that through authentic assessment, the learning process may be understood in real terms in light of the facts regarding the status of students learning English. According to Nurgiyantoro (2011), authentic assessment is an evaluation of performance that is also meaningful.

Based on the above opinion regarding reading skills by developing authentic assessments through the scaffolding model, then as an outstanding basic research team at Samudra University, conducted initial observations to find out how the English learning process was carried out in learning activities. Initial observations are our initial data to conduct this research. It turns out that many teachers do not use the scaffolding model in learning activities and also never carry out assessments using authentic assessments of students in English subjects. That's why we are interested in researching by providing knowledge to teachers and students by using scaffolding models and authentic assessments of English reading skills in learning activities.

\section{METHODS}

This study employs a research and development methodology based on Thiagarajan and Sammel's 4D paradigm, defining, designing, developing, and disseminating (1974). This research was conducted in order to design a product through evaluation. The researcher collected data for this study through expert validation, specifical data on the quality of the feasibility of Authentic Assessment Instruments Oriented Reading Skills, development outcomes in the form of expert validation results, materials, and teachers. The data set includes assessment scores for construction, material content, and language. The response data derived from the test findings are from field testing. The data from the field trials are divided into three stages: validation, reliability testing, and implementation. As a result, the study instrument is comprised of a questionnaire/feasibility assessment, observation sheets, and the findings of the Reading Skills Test. The study employs the following data analysis techniques: (1) feasibility analysis of authentic instruments; (2) feasibility analysis of students' reading skills worksheets; and (3) validation and reliability trials.

\section{FINDINGS AND DISCUSSION \\ Initial Investigation Phase}

At this stage, analysis of needs research is carried out, analysis of authentic assessment instruments for English learning, curriculum analysis, and student analysis. Needs analysis is done by analyzing existing studies, especially the problem of language literacy. Based on the analysis results, information was obtained that the language literacy skills of students was in a low category. One of the contributing factors is that students are not accustomed to working on language literacy-based questions. This is what underlies the researcher to conduct further analysis, namely 
the analysis of authentic assessment instruments for English learning used by schools. Based on the results of the analysis of the English learning instruments used in schools, information was obtained that the authentic assessment instruments did not meet the criteria for language literacy both in terms of competence and cognitive level, so it was necessary to develop an authentic assessment instrument based on language literacy to train students' language literacy skills.

Curriculum analysis is carried out so that the authentic assessment instrument produced refers to the applicable curriculum. The curriculum that is used as a reference is the revised 2013 curriculum. In addition, this analysis is carried out to determine the limitations of the material studied and the selection of material focused on developing the assessment instrument. Based on the results of the curriculum analysis, the design of scientific literacy-based assessment instruments focused on basic competencies (KD), namely reading comprehension. Furthermore, the formulation of learning indicators is carried out. Student analysis was carried out to determine students who had high, medium, and low abilities.

\section{Development or Prototyping Stage}

At this stage, the research team validated the authentic assessment instrument for reading comprehension skills in English literacy. To find out the validation results can be seen in Figure 1 below.

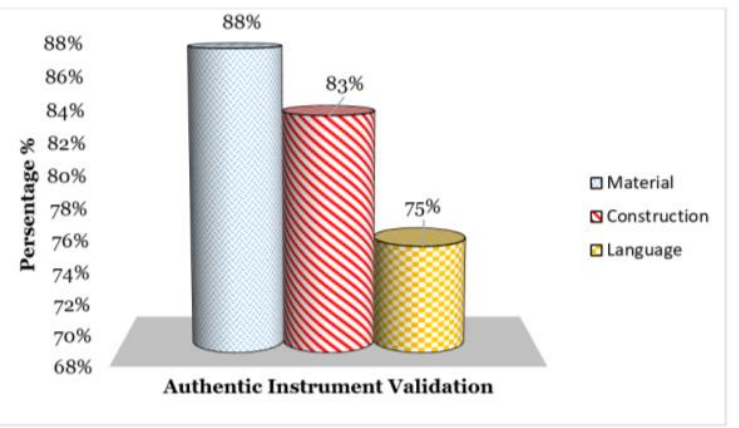

\section{Figure 1. Authentic Instrument Validation}

Based on the results of expert validation, the percentage of authentic instrument eligibility in the content aspect is $88 \%$, the language aspect is $83 \%$, and the format aspect is $75 \%$, it can be categorized as an authentic assessment instrument suitable for research.

\section{Assessment Stage}

The assessment stage is a field test stage. This stage aims to obtain empirical validity data and practical tests of the developed authentic assessment instrument. This stage was carried out by asking 20 students to work on the developed language literacy-based authentic assessment instrument. Then ask them to fill out a practicality test questionnaire can be seen in Figure 2 below: 


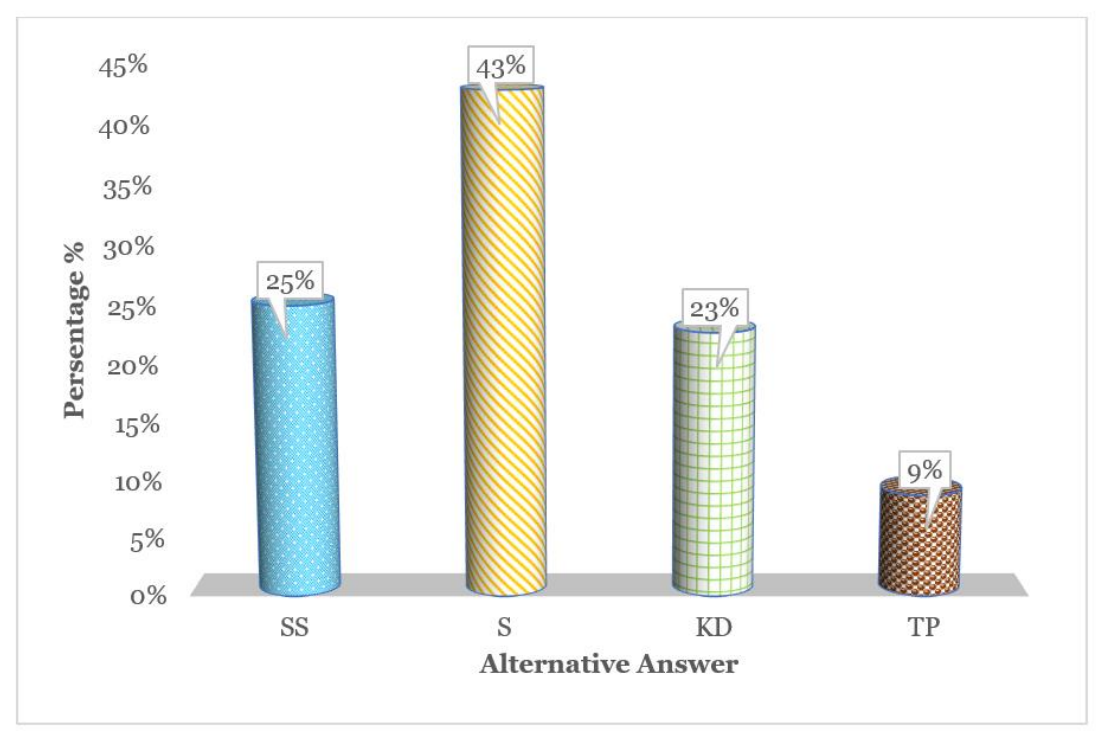

Figure 2. Practical Test of Instruments

Based on the numbers in the graph above regarding students' reading comprehension in English as a student worksheet consisting of four alternative answers, namely very often with a value of $25 \%$ stated as practical, often with a value of $43 \%$ stated very practical, sometimes with a value of $23 \%$ stated practical while never with a value of $9 \%$ is declared impractical.

Submission of authentic assignments is based on preventive actions to avoid what Abidin (2012) stated that one of the big mistakes made by the teacher was not correctly outlining the authentic reading tasks that students had to do during learning. Using the scaffolded reading method, the students' reading comprehension learning outcomes always increase (Putri \& Yuanita, 2018). In line with Ahmad's research (2017) results, which concluded that there was an increase in reading skills given to students by $6.98 \%$. Sudarman and Linuhung (2017) also show that the Scaffolding learning model can improve students' understanding of concepts in mathematics. The results of this study are relevant to the research conducted by Rahmawati (2016), which states that there is an effect of applying the scaffolding learning model to the mathematics learning outcomes.

\section{CONCLUSION}

Based on the results of the above research, which consists of the product development stage of an authentic assessment instrument oriented towards language literacy-based reading skills using the Scaffolding model, it can be concluded as follows: (1) The Preliminary Research Phase describes the results of curriculum analysis, then the design of an assessment instrument based on scientific literacy is focused on basic competence (KD) on reading comprehension while student analysis is carried out to determine students who have high, medium, and low abilities; (2) the product development stage that performs expert validation, the percentage of authenticity instrument eligibility consisting of three indicators is $82 \%$, it can be concluded that the instrument is suitable for use in the process of learning activities; (3) The practicality stage given to 20 students in a Senior High School at Aceh Tamiang Regency, consisted of four alternative answers, $25 \%$ were declared practical. The average value of students' reading skills in the first cycle was 71.3\% and included in the good category.

The instrument for assessing early reading skills in early childhood has very high validity, so it is feasible. The implication of implementing this development research is to produce a product in the form of an instrument for assessing early childhood reading skills that are valid and can be used in the learning process. Reading in early childhood is not the same as reading in adults. Reading in early childhood is better known as early reading, which is in the early stages of 
translating written symbols into sounds. Language development is the main basis in language development through rich communication experiences.

\section{ACKNOWLEDGMENT}

Thank you to LPPM \& PM Universitas Samudra for providing excellent basic research funds so that the research activity process runs smoothly until the time.

\section{REFERENCES}

Abidin, Y. (2012). Pembelajaran membaca berbasis pendidikan karakter. Bandung: Refika Aditama.

Ahmat, A. (2017). Penerapan Permainan Bahasa (Katarsis) Untuk Meningkatkan Keterampilan Membaca Siswa Kelas IV A SD Negeri 01 Metro Pusat. Jurnal Pendidikan Dasar, 9(2): 79-83. doi: https://doi.org/10.17509/eh.v9i2.7024.

Adnan, Yamin, M., Aulia, M., \& Kurniawati, R. (2019). Penggunaan Big Book Dalam Pembelajaran Membaca Permulaan Di Sekolah Dasar. Jurnal Basicedu, 3(3), 963-969. Retrieved Form: https://doi.org/10.31004/basicedu.v3i3.245.

Aisyah, S., Yarmi, G., Sumantri, M. S., \& Iasha, V. (2020). Kemampuan Membaca Permulaan Melalui Pendekatan Whole Language di Sekolah Dasar. Jurnal Basicedu, 4(3), 637-643. Retrieved Form: https://doi.org/10.31004/basicedu.v4i3.393.

Anggraeni, S. W., \& Alpian, Y. (2019). Penerapan metode Teams Games Tournament (TGT) untuk meningkatkan kemampuan membaca permulaan siswa kelas I sekolah dasar. Premiere Educandum, 9(2), 181-193. Retrieved Form: https://doi.org/10.25273/pe.vgi2.5086.

Bambang. (2011). Penerapan Digital Library Sebagai Langkah Strategis Menstimulasi Budaya Membaca Di Masyarakat [Online]. Tersedia: Retrieved Form: http://pustaka.uns.ac.id/?opt=1001\&menu=news\&option=detail\&nid=346.

Departemen Pendidikan Nasional. Kurikulum 2013 Kompetensi Inti dan Kompetensi Dasar Bahasa Indonesia, Diknas, Jakarta.

Dalman. (2014). Keterampilan Membaca. Jakarta: Rajawali Pers.

Fauziah, H. (2018). Upaya Guru Dalam Mengembangkan Kemampuan Membaca Menulis Permulaan Siswa Kelas I MI. Elementary: Jurnal Ilmiah Pendidikan Dasar, 4(2), 173-184. Retrieved Form: https://doi.org/10.32332/elementary.v4i2.1241.

Fitriana Rahmawati, (2016). Pengaruh Penerapan Model Pembelajaran Scaffolding terhadap Hasil Belajar Matematika pada Siswa Kelas VIII Semester Ganjil SMP Negeri 30 Bandar Lampung. (Lentera STKIP-PGRI Bandar Lampung: Vol 1, 2016), 145-154.

Gibbons, Pauline. (2002). Scaffolding Language, Scaffolding Learners: Teaching Second Language Learners in the Mainstream Classroom. Portsmouth: Heinemann.

Gustiawati, R., Arief, D., \& Zikri, A. (2020). Pengembangan Bahan Ajar Membaca Permulaan dengan Menggunakan Cerita Fabel pada Siswa Sekolah Dasar. Jurnal Basicedu, 4(2), 355360. Retrieved Form: https://doi.org/10.31004/basicedu.v4i2.339.

Krismanto, W., Khalik, A., Sayidiman. (2015). Meningkatkan Kemampuan Membaca Pemahaman Melalui Metode Survey, Question, Read, Recite, Review (SQ3R) Pada Siswa Kelas IV SD Negeri 46 Parepare. Jurnal Publikasi Pendidikan. 5(3): 234-242. doi: https://doi.org/10.26858/publikan.v5i3.1616.

Khairunnisak. (2015). Efektifitas Media Kartu Dalam Pembelajaran Membaca Permulaan. Jurnal Ilmiah Didaktika: Media Ilmiah Pendidikan Dan Pengajaran, 15(2), 136-155. Retrieved Form: https://doi.org/10.22373/jid.v15i2.577.

Komarudin, \& Widyana, R. (2016). Efektivitas Metode Analisis Glass Untuk Meningkatkan Kemampuan Membaca Permulaan Pada Anak Berkesulitan Membaca Kelas III Sekolah Dasar. Insight: Jurnal Ilmiah Psikologi, 18(2), 178-190. Retrieved Form: https://doi.org/10.26486/psikologi.v18i2.381.

Kharisma, G. I., \& Arvianto, F. (2019). Pengembangan Aplikasi Android Berbentuk Education Games Berbasis Budaya Lokal untuk Keterampilan Membaca Permulaan Bagi Siswa Kelas 1 SD/MI. Premiere Educandum: Jurnal Pendidikan Dasar Dan Pembelajaran, 9(2), 203-213. Retrieved Form: https://doi.org/10.25273/pe.vgi2.5234. 
Majdi Abdullah Ahmad AD-Heisat, Syakirah Mohammed, K.A. Sharmella, Krishnasamy, dan Jenan H. Issa. (2009). The Use of Reading Strategies in Developing Students' Reading Competency among Primary School Teachers in Malaysia. European Journal of Social Sciences. $\quad$ 12(2), 310-319. Retrieved Form: https://www.researchgate.net/publication/283325592.

Nurgiyantoro, B. (2011). Penilaian Otentik dalam Pembelajaran Bahasa. Yogyakarta: Gadjah Mada University Press.

Nahdi, K., \& Yunitasari, D. (2020). Literasi Berbahasa Indonesia Usia Prasekolah: Ancangan Metode Dia Tampan dalam Membaca Permulaan. Jurnal Obsesi : Jurnal Pendidikan Anak Usia Dini, 4(1), 434- 441. Retrieved Form: https://doi.org/10.31004/obsesi.v4i1.372.

Putri, A.M., Cece, R., \& Dian.I. (2014). Penerapan Teknik Scaffolding Dalam Pembelajaran Membaca Pemahaman Literasi Bahasa Inggris. Jurnal Ilmiah Mahasiswa Pendidikan Guru Sekolah Dasar. 1(2). 54-61. Retrieved Form: http://pgsd-tasikmalaya.upi.edu/.

Putri, M.A., \& Yuanita, S. (2018). Efektivitas Teknik Scaffolding untuk Mengembangkan Strategi Metakognisi dalam Meningkatkan Keterampilan Mengeja Saat Menulis pada Anak ADHD. Jurnal , 1(1): 17-32. Retrieved Form: http://ejournal.radenintan.ac.id/index.php/anfusina ajp.v1i1.3610.

Pratiwi, W.K., Gading, K.I., \& Antara, A.P. (2021). Instrumen Penilaian Kemampuan Membaca Permulaan Pada Anak Usia Dini. Journal for Lesson and Learning Studies, 4(1): 33-38. Retrieved Form: https://ejournal.undiksha.ac.id/index.php/JLLS.

Rahman, B., \& Haryanto, H. (2014). Peningkatan Keterampilan Membaca Permulaan Melalui Media Flashcard Pada Siswa Kelas I Sdn Bajayau Tengah 2. Jurnal Prima Edukasia, 2(2), 127. https://doi.org/10.21831/jpe.v2i2.2650.

Rachmawaty, M. (2017). Penigkatan Kemampuan Membaca Permulaan Melalui Dinding Kata (Word Wall). Jurnal Indria: Jurnal Ilmiah Pendidikan Prasekolah Dan Sekolah Awal, 2(1). Retrieved Form: https://doi.org/10.24269/jin.v2n1.2017.pp28-44.

Siahaan, S. \& Shinoda, K. (2008). Generic text structure. Yogyakarta: Graha Ilmu.

Santosa, S. H., Dantes, N., Rasna, W., Antara, I. G. P., \& Lama, K. (2016). Studi Eksperimentasi dan Penelusuran Keefektifan dan Efisiensi Metoda dalam Proses Belajar Membaca Permulaan di Sekolah Dasar. Jurnal Ilmu Pendidikan, 2(4). Retrieved Form: https://doi.org/10.17977/jip.v2i4.2303.

Sudarman, Satrio, W., \& Nego, L. (2017). Pengaruh Pembelajaran Scaffolding terhadap Pemahaman Konsep Integral Mahasiswa. (Jurnal: Pendidikan Matematika FKIP Universitas Muhammadiyah Metro, Vol 1, 2017), 33-39

Supriyono, Y. (2018). Efl Learners' Reading Learning In Web Based Instruction Setting. Edulite: Journal of English Education, Literature, and Culture. 3(1), 91-100. Retrieved Form: http://jurnal.unissula.ac.id/index.php/edulite/article/view/2147.

Van de Pol, J., Volman, M., \& Beishuizen, J. (2010). Scaffolding in teacher-student interaction: A decade of research. Educational psychology review, 22(3), 271-296.

Van Geert, P., \& Steenbeek, H. (2005). The dynamics of scaffolding. New ideas in Psychology, 23(3), 115-128.

Walqui, Aida. (2006). Scaffolding Instruction for English Language Learners: A Conceptual Framework. The Internet Journal of Bilingual Education and Bilingualism. 9(2), 159-181. Retrieved Form: https://www.tandfonline.com/doi/abs/10.1080/13670050608668639. 